Article

\title{
Study on Landscape Ecological Classification and Landscape Types Evolution: A Case Study of a Mining City in Semi-Arid Steppe
}

\author{
Zhenhua Wu ${ }^{1,2,3}$, Qingqing Lu ${ }^{3}$, Shaogang Lei ${ }^{1, *}$ and Qingwu Yan ${ }^{3, *}$ \\ 1 Engineering Research Center of Ministry of Education for Mine Ecological Restoration, China University of \\ Mining and Technology, Xuzhou 221116, China; wuzhenhua@cumt.edu.cn \\ 2 School of Economics and Management, China University of Mining and Technology, Xuzhou 221116, China \\ 3 School of Public Policy \& Management, China University of Mining and Technology, Xuzhou 221116, China; \\ luluqingzi@163.com \\ * Correspondence: lsgang@126.com (S.L.); yanqingwu@cumt.edu.cn (Q.Y.)
}

Citation: Wu, Z.; Lu, Q.; Lei, S.; Yan, Q. Study on Landscape Ecological Classification and Landscape Types Evolution: A Case Study of a Mining City in Semi-Arid Steppe.

Sustainability 2021, 13, 9541

https://doi.org/10.3390/su13179541

Academic Editor: Nađa Beretić

Received: 29 July 2021

Accepted: 10 August 2021

Published: 25 August 2021

Publisher's Note: MDPI stays neutral with regard to jurisdictional claims in published maps and institutional affiliations.

Copyright: (c) 2021 by the authors. Licensee MDPI, Basel, Switzerland. This article is an open access article distributed under the terms and conditions of the Creative Commons Attribution (CC BY) license (https:// creativecommons.org/licenses/by/ $4.0 /)$.

\begin{abstract}
Landscape Ecological Classification (LEC) is the premise and foundation of landscape ecology research. The current research on LEC of Mining Cities in the Semi-arid Steppe (MCSS) is relatively low. Moreover, the question of how to classify the mining landscape into ecologically significant landscape units at a scale suitable for ecological management has not been clear. The research results are as follows: (1) Google Earth, Gaode map, Baidu map, various high-resolution images, unmanned aerial vehicle, and field investigation were used to investigate the landscape types. Based on the land classification of the occurrence model, integrating theories of landscape ecology, mining, ecology, geography, and land resources, this study constructed the LEC system for MCSS using the top-down decomposition classification method, including 4 types of landscape kingdom, 16 types of landscape class, 62 types of landscape family, and more than 200 types of landscape species. (2) Based on LEC, we found the landscape type evolution characteristics of MCSS. Both the open-pit landscape and the dumping landscape were constantly expanding, and ecological restoration of the mining area was carried out simultaneously with coal mining. The trend of Change Intensity (CI) of mining industrial square landscape and industrial storage landscape was very similar. The development of coal has driven the development of the regional industry. The expansion intensity of the town commercial and residential service landscape was gradually decreasing, and the motivation for town expansion was insufficient. The research area was a typical landscape evolution mode of "human advance and grassland retreat". However, the intensity of humans occupying grassland was decreasing. This study provides a reference for the research of LEC in the semi-arid steppe and provides a theoretical basis for the landscape ecological assessment, planning, and management of mining cities.
\end{abstract}

Keywords: landscape ecological classification; landscape types evolution; semi-arid steppe; mining city

\section{Introduction}

Coal is the most important component of the world's energy structure and the most important energy source for the Chinese economy [1]. With the development of the social economy, the demand for mineral resources is increasing, which has pulled or stimulated the rapid development of the mining industry. In turn, the mining industry has promoted the rapid development of the social economy [2]. In order to further meet China's energy demand, the Chinese government focused on the construction of 14 large-scale coal bases and 16 large-scale coal-power bases. Most of them are located in arid/semi-arid areas. For decades, rapid economic growth and the improvement of human living status for China have been accomplished at the expense of environmental integrity [3]. Grassland accounts for about $20 \%$ of the total land area of the world [4]. Serious degradation of semi-arid 
steppe worldwide has negative consequences for local, regional, and global ecosystem services [5]. Long-term high-intensity mining results in desertification of land, the spread of pollution, landscape fragmentation, degradation of habitat and landscape ecological functions, and ecological imbalances in the semi-arid steppe. The Mining area Landscape Ecological Classification (LEC) is the basis of the analysis and simulation of landscape patterns, the basic method of clarifying the impact mechanism of mineral exploitation on regional landscape ecology, and a tool for studies of landscape ecological restoration. The research on the theory and methodology of LEC, to a large extent, reflects the whole study level on the landscape ecology of the mining area.

In LEC research, the Soviet Union [6] and others understood landscape as a certain level of classification units from the perspective of geography. LEC research for the North American school [7] and others transformed land use classification systems because they paid attention to research on landscape patterns and ecological functions. European school was the birthplace of LEC [8]. In recent years, a large number of scholars have studied the LEC of European countries [9-12]. Chinese scholars Duning Xiao [13], Yanglin Wang [14], and others introduced LEC theory into China. Afterwards, Weiming Cheng [15], Huarong Zhou [16], Luo Guo [17], Zhenpeng Li [18], Qingdong Shi [19], Yuguo Qian [20], Qingzu Luan [21], Guo Li [22], and others put the theory into practice in order to solve the problem of regional ecological environment. The current status of LEC research is mostly limited to macroscopic classification of largescale and mesoscale landscape and less involved in the division of small-scale landscape types, especially the classification of severe human disturbance in mining areas. In recent years, the developments and management of a single mineral resource have produced a series of serious social and ecological consequences, emphasizing that the LEC of mining scales according to ecological attributes is gradually becoming a hot topic. At present, most of the mining areas' LEC draws on the existing land cover and LEC systems such as "Technical regulation of the third nationwide land survey (TD/T1055-2019)" [23] or land use classification systems adapted to the actual research needs [24]. Rixing He divided mining areas into the following four categories: natural landscape, agricultural landscape, artificial landscape, and anthropogenic landforms [25]. Yanglin Wang divided mining areas into the following three categories: large agricultural areas outside mine, capital construction areas, and environmental protection and service functions areas [26]. Xingfeng Wang [27] had constructed three categories of landscape types, landscape system, and landscape components. Jianjun Zhang [28] divided mining landscapes into restoration landscapes, limited restoration landscapes, and protection landscapes. At present, there is little research on the LEC in mining areas. In the theoretical domain, the landscape spatial structure, ecological attributes, and landscape functions have been emphasized, while ignoring ecological processes. In the empirical research domain, most of the study has been focused on the high phreatic level, semi-humid plains, and abandoned mining areas, with a lack of research on open-pit mines and, especially, a lack of Mining Cities in the Semi-arid Steppe (MCSS) LEC system construction research.

MCSSs are located in the frigid and arid regions. The plant growth period is short, the biomass is low, the biological chain is simple, and the processes of material circulation and energy conversion in the ecosystem are slow, which renders the regional ecological environment fragile. High-intensity and large-scale coal-power development and utilization are considered to be the main cause of landscape ecological change in the grassland mining area. Therefore, systematically carrying out basic research on the landscape structure, function, and process of MCSS under high-intensity mining disturbances and researching key technologies for MCSS landscape ecological restoration have an important supporting role for the sustainable development of MCSS and regional ecological security. Landscape restoration and reconstruction are for landscape degradation, the landscape degradation from the form of expression can be divided into landscape structure and function degradation [29]. The objective of LEC is to reduce the structural and functional complexity of MCSS in models while quantifying key social and ecological processes involved in shaping current ecosystem conditions [30]. The degradation or restoration of certain key 
nodes, patches, and corridors in the landscape plays a vital role in regional sustainable development. The construction of the LEC system can identify these key elements from large-scale and provide top-level guidance for subsequent landscape ecology research in mining areas. Characteristic analysis and pattern evolution on landscape types have become an important content of the studies on global environmental changes [31,32]. During the landscape type pattern change process, materials are recycled and energy flows between human activities and ecological environments. The change of landscape type is characterized by the obvious and sudden man-made impact on the ground surface, which results in fundamental changes in landscape pattern and function, and this impact is often irreversible. Open-pit mining activities will inevitably affect landscape type patterns, even disastrously in some cases. At present, landscape type pattern changes have also become a hot topic in mine areas [33]. Mine areas are at a small scale and severely disturbed by landscape destruction such as excavation and occupancy, resulting in remarkably rapid landscape type pattern changes with easily identified influence factors [34,35]. As a special geographical area, the landscape pattern evolution of the mining area is a dynamic spatiotemporal evolution process with resource exploitation as the driving force and is a comprehensive reflection of the impact of mining on the regional ecosystem. It is of great significance to study the landscape pattern evolution of mining areas for understanding the impact of mining on the regional ecosystem. Landscape pattern evolution analysis is a necessary method for studying the impact of mining on the landscape ecology of semi-arid grassland. However, most of the existing studies incorporate mining landscape into the industrial storage landscape, so it is difficult to explore the impact of mining on grassland landscape ecology through the evolution of landscape types [36]. In this context, this paper aims to (1) investigate and analyze the landscape ecological types of MCSS; (2) propose a LEC system suitable for MCSS; and (3) select a typical study area for landscape types evolution characteristics analysis.

\section{Materials and Methods}

\subsection{Study Area}

The study area is located in Xilinhot City, Xilinguole League, Inner Mongolia Autonomous Region, China (Figure 1). Xilinhot City is a typical mining city where multiple mineral resources such as coal, petroleum, and metals are simultaneously developed. Xilinhot City belongs to the large-scale coal base and large-scale coal-power base of Eastern Inner Mongolia.
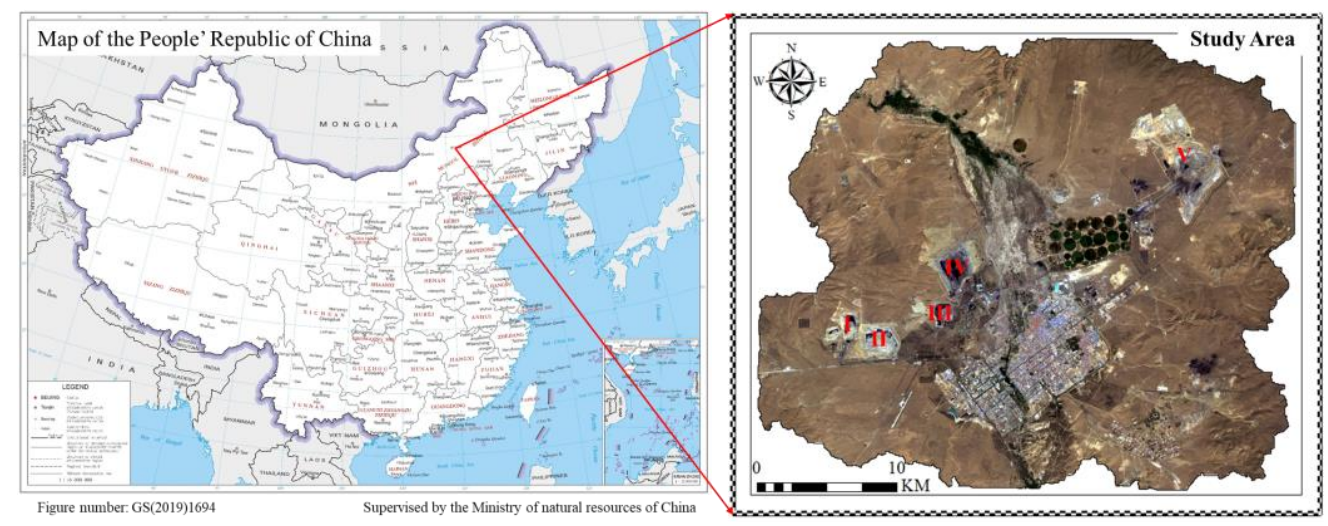

Figure 1. Location of the research area. I: Surface germanium mine; II: West No. 2 surface mine; III: West No. 3 surface mine; IV: No. 1 surface mine; and V: East No. 2 surface mine (Remarks: The picture on the left was downloaded from China National Catalogue Service For Geographic Information. The picture on the right was Landsat OLI (No.: LC81240292017198LGN00)). 


\subsection{Data Source and Preprocessing}

The Landsat data of the study area were downloaded from the United States Geological Survey website (Table 1). The ENVI 5.3 software was used for remote sensing image preprocessing. Normalized Difference Vegetation Index (NDVI) [37] was calculated by using bands of Landsat. Ecological Service Function (ESF) adopted the existing research results of the author [38,39]. NDVI and ESF were normalized to 0 to 1 (Figure 2).

Table 1. Landsat Data.

\begin{tabular}{ccc}
\hline Time & Number & Type \\
\hline 2002-07-08 & LT51240292002189BJC00 & Landsat 5 \\
$2005-08-17$ & LT51240292005229BJC02 & Landsat 5 \\
2008-07-08 & LT51240292008190BJC00 & Landsat 5 \\
$2011-08-02$ & LT51240292011214IKR00 & Landsat 5 \\
$2014-07-25$ & LC81240292014206LGN00 & Landsat 8 \\
2017-07-17 & LC81240292017198LGN00 & Landsat 8 \\
\hline
\end{tabular}

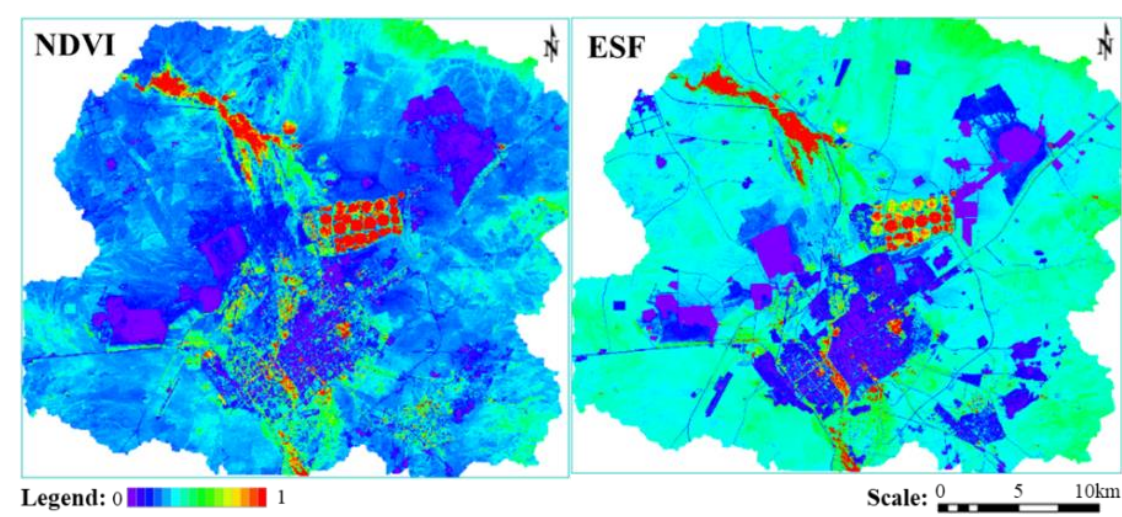

Figure 2. The results of NDVI and ESF [38,39].

\subsection{Research Methods}

\subsubsection{Landscape Ecological Classification}

Firstly, the landscape types in the study area were identified indoors by using Google Earth, Google map, Gaode map, Baidu map, and various high-resolution images. Then, we focused on the field investigation of the landscape types that cannot be identified or confirmed indoors and took a lot of field investigation photos. According to the survey results, based on the land classification of the occurrence method and fully considering the ecological attributes of the land, integrating theories of landscape ecology, mining, ecology, geography, and land resources, this study adopted the top-down decomposition classification method in order to construct the LEC system of MCSS. In this study, the support vector machine combined with visual interpretation was used for LEC mapping.

\subsubsection{Landscape Types Evolution}

(1) Analysis on change intensity characteristics of main landscape types in the study area.

Change Intensity (CI) of a landscape type can be used to compare the intensity and speed of a landscape type change in different periods. It is defined by Equation (1). The greater the value of $C I$ is, the faster a landscape type changes:

$$
C I=\frac{U_{b}-U_{a}}{A} \times \frac{1}{\Delta t} \times 100 \%
$$

where $C I=$ Change Intensity; $U_{a}=$ the area a landscape type at the beginning of research period; $U_{b}=$ the area a landscape type at the end of research period; $A=$ total area of research area; and $\Delta t=$ research period. 
(2) Dynamic degree of spatial change of landscape types in the study area.

The dynamic degree of landscape type spatial change can be used to reflect the speed of a landscape type in and out of space. The calculation formula is as follows:

$$
D=\frac{\Delta U_{i n}+\Delta U_{o u t}}{U_{b}} \times \frac{1}{\Delta t} \times 100 \%
$$

where $\Delta U_{i n}$ is the total area of other landscape types transformed into this type in the study stage. $\Delta U_{o u t}$ is the total area of a landscape type changing into other landscape types in the study stage. $U_{b}$ is the area of a landscape type at the end of the study period. When $\Delta t$ is set as a year, the value of $D$ is the dynamic degree of spatial change of the landscape type in the study area.

\subsection{Landscape Ecological Analysis of MCSS}

There are two main types of coal mining: shaft mining and surface mining [40]. In the process of surface coal mining, the types of landscape are listed as follows: excavation landscape, occupied landscape, piled-up landscape, and undisturbed landscape [41]. Excavation landscape is formed by stripping the surface soil, the overburden, or the middle layer of the coal seam during the mining process in order to obtain the underground coal resources (Figure 3a). The occupied landscape mainly refers to the dump, which is used for stacking the stripped substance in the surface mine. The interior of the dump will pile up gangue, weathered rock and soil, hard rock, and mixed rock and soil, the surface of which is covered with a certain thickness of humus topsoil in order to grow vegetation. In the early stages of exploitation, the stripping material is stacked outside the scope of the open-pit mine, called the external dumping (Figure 3c). When the openpit is formed, the stripping material is backfilled within the scope of the open-pit mine, which is called internal dumping (Figure $3 b$ ). The occupied landscape includes the coal preparation plant, coal washing plant, coal transportation corridor (Figure 3f), railways, all kinds of roads, industrial squares, pipelines, and transmission lines, all of which are for coal development services.

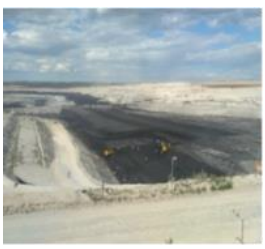

(a)

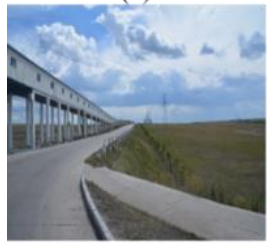

(f)

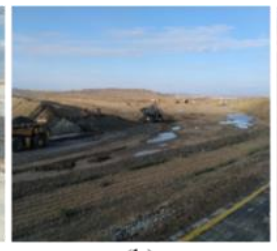

(b)

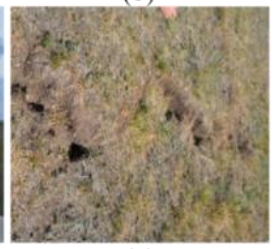

(g)

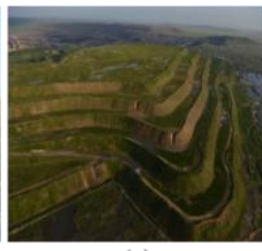

(c)

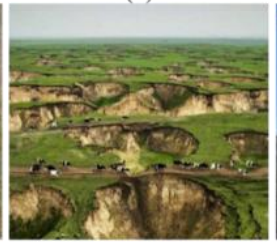

(h)

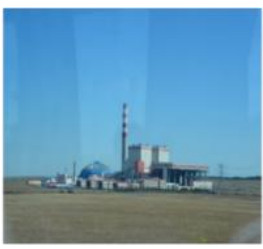

(d)

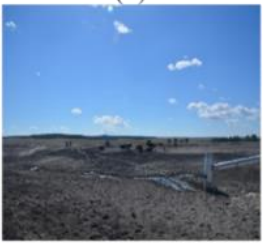

(i)

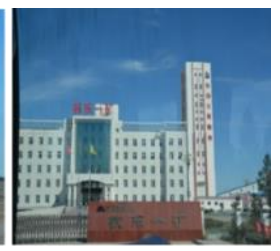

(e)

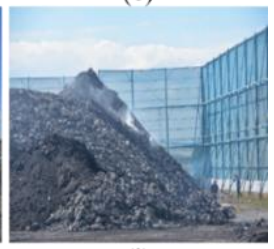

(j)

Figure 3. Landscape Ecological Types of MCSS: (a) open-pit; (b) internal dumping; (c) external dumping; (d) thermal power plant; (e) mining industrial square; (f) coal transportation corridor; (g) ground fissure; (h) subsidence land; (i) coal fly ash dumps; (j) coal gangue dumps (Remarks: Picture (h) was a network picture; the rest of the pictures were taken in the field by the author).

The landscape types produced by shaft mining include the following: (1) mining facilities landscape, mainly used for coal mining, screening, and transportation and other constructed sites such as coal preparation plant, coal transportation corridor (Figure 3f), and so on; (2) mining office landscape (Figure 3e), mainly used for coal mine staff office and living places, such as office buildings, canteen, workers' village, dormitory buildings, and so on; (3) mining disturbing landscape is formed by high-intensity interference from 
coal mining, which mainly refers to the subsidence land (Figure $3 \mathrm{~h}$ ) and ground fissures (Figure 3g); (4) occupied landscape refers to solid mine waste discharge and abandoned land (Figure 3j). Upon closure of the mine, the areas are generally reclaimed for agricultural land, gardens, woodland, construction land, livestock land, aquaculture land, or mine parks. According to the China National Mine Park Construction Work Guide [42], the relict mining landscapes are divided into five categories: mineral geological relicts, mining production relicts, mining relicts for social life, mining products, and mineral development literature and history. Thermal power plant landscapes (Figure 3d) mainly include (1) coal transportation corridor, road, or railway; (2) construction land inside the thermal power plant, including office, raw coal hopper, coal mill, powder coal bunker, boiler, steam turbine, generator, chimney, condensing tower, transformer, and so on; (3) high voltage transmission network; and (4) coal fly ash dumps formed from coal combustion (Figure 3i).

\section{Results}

\subsection{Construction of LEC System of MCSS}

According to the hierarchical nomenclature of biological classification, the four levels of the LEC system of this study are named landscape Kingdom, Class, Family, and Species and include 4, 20, 67, and more than 200 landscape types, respectively (Table 2).

Table 2. Landscape ecological classification system of MCSS.

\begin{tabular}{|c|c|c|c|}
\hline Kingdom & Class & Family & Species \\
\hline \multirow{15}{*}{$\begin{array}{l}\text { Mining } \\
\text { landscape }\end{array}$} & \multirow{2}{*}{ Open-pit landscape } & Open-pit-slope & Working/Non-working face-slope \\
\hline & & Open-pit-flat & Working/Non-working face-flat \\
\hline & \multirow{2}{*}{ Dumping landscape } & Internal dumping landscape & \multirow{2}{*}{$\begin{array}{l}\text { Internal dumping (non-)vegetation-covered/External } \\
\text { dumping slope (platform)/Stacking outside dumping }\end{array}$} \\
\hline & & External dumping landscape & \\
\hline & \multirow{3}{*}{$\begin{array}{l}\text { Mining industrial square } \\
\text { landscape }\end{array}$} & Thermal power plant landscape & $\begin{array}{l}\text { Road/Office/Raw coal hopper/Coal mill/Powder coal } \\
\text { bunker/Boiler/Steam turbine/Generator /Transformer }\end{array}$ \\
\hline & & Mining facilities landscape & Mine/Coal preparation plant/Coal transportation corridor \\
\hline & & Mining office landscape & Office/Canteen/Workers' village/Dormitory building \\
\hline & \multirow{3}{*}{ Mining relics landscape } & $\begin{array}{l}\text { Mineral geological relics } \\
\text { landscape }\end{array}$ & $\begin{array}{l}\text { Typical deposit and its geological profile/Prospecting } \\
\text { criteria and flags/Mining space relics/Landform and } \\
\text { Geological landscape/Geological environment change and } \\
\text { the geological disaster relics }\end{array}$ \\
\hline & & $\begin{array}{l}\text { Mining production relics } \\
\text { landscape }\end{array}$ & $\begin{array}{l}\text { Exploration relics /Mining relics/Beneficiation } \\
\text { relics/Smelting processing relics }\end{array}$ \\
\hline & & $\begin{array}{l}\text { Mining relics for social life } \\
\text { landscape }\end{array}$ & $\begin{array}{l}\text { Site of social life and belief activities place or relics/Miners } \\
\text { clothing and articles remains/Social customs } \\
\text { remains/Institutions, facilities, equipment, and related } \\
\text { remains of social management or relics }\end{array}$ \\
\hline & \multirow{5}{*}{$\begin{array}{l}\text { Mining disturbing } \\
\text { landscape }\end{array}$} & Mining waste bare & Pollution-free/ Contaminated \\
\hline & & Subsided land & Stable/Unstable subsidence \\
\hline & & Ground fissure & Stable/Unstable ground fissure \\
\hline & & Coal fly ash dumps & Bead particle/Slag particle \\
\hline & & Coal gangue dumps & Stop Stacking/Stacking Gangue Dumps \\
\hline
\end{tabular}


Table 2. Cont.

\begin{tabular}{|c|c|c|c|}
\hline Kingdom & Class & Family & Species \\
\hline \multirow{22}{*}{ Town landscape } & \multirow{6}{*}{$\begin{array}{l}\text { Town commercial and } \\
\text { residential service } \\
\text { landscape }\end{array}$} & Town residential landscape & Urban/Township/Country/Village Residential Areas \\
\hline & & Business service landscape & $\begin{array}{l}\text { Commercial/Recreation and sports/Public facilities } \\
\text { outlets/Other business services }\end{array}$ \\
\hline & & $\begin{array}{l}\text { Public management and public } \\
\text { service }\end{array}$ & $\begin{array}{l}\text { Administration/Culture/Education/ Sports/ Sanitary } \\
\text { facilities }\end{array}$ \\
\hline & & Mining reconstruction landscape & $\begin{array}{l}\text { Reconstruction mining residential/Business Service/Public } \\
\text { management and public service }\end{array}$ \\
\hline & & Special landscape & Military Affairs/Security Landscape \\
\hline & & Construction site landscape & Idle construction site/Construction and demolition site \\
\hline & \multirow{4}{*}{$\begin{array}{l}\text { Industrial and storage } \\
\text { landscape }\end{array}$} & Industrial landscape & A/B/C Class industrial landscape \\
\hline & & $\begin{array}{l}\text { Reconstruction industrial } \\
\text { landscape of mining area }\end{array}$ & $\begin{array}{l}\text { Reconstruction industrial, storage, and surface pipeline } \\
\text { transportation landscape of mining area }\end{array}$ \\
\hline & & Storage landscape & Commonly/Special storage landscape \\
\hline & & Surface pipeline transportation & $\begin{array}{l}\text { Oil and natural gas surface pipeline transport and affiliated } \\
\text { facilities }\end{array}$ \\
\hline & \multirow{6}{*}{ Greenland landscape } & Park greenland landscape & $\begin{array}{l}\text { Comprehensive park/Theme park/ Belt park/Other park } \\
\text { greenlands }\end{array}$ \\
\hline & & $\begin{array}{l}\text { Reconstruction greenland } \\
\text { landscape of mining area }\end{array}$ & Reconstruction park/Public/Production greenland \\
\hline & & Road greenland landscape & $\begin{array}{l}\text { Road green belt/Traffic island greenland/Parking } \\
\text { greenland }\end{array}$ \\
\hline & & $\begin{array}{l}\text { Residential areas and units } \\
\text { attached greenland landscape }\end{array}$ & Residential areas/Units attached greenland \\
\hline & & $\begin{array}{l}\text { Production and defense greenland } \\
\text { landscape }\end{array}$ & $\begin{array}{l}\text { Comprehensive production greenlands / Pure productive } \\
\text { greenlands/Urban shelterbelt /Sanitary isolation } \\
\text { belt/Safety shelterbelt/Urban high-pressure corridor green } \\
\text { belt/City group isolation belt }\end{array}$ \\
\hline & & Public greenland landscape & Group greenland/Other public greenlands \\
\hline & \multirow{6}{*}{ Agricultural landscape } & Dry farmland & $\begin{array}{l}\text { Corn/Soybean/Wheat/Naked Oats/ Potato/Flax/Hill } \\
\text { potherb/Beet/Mixed beans/Carrot and other dry land }\end{array}$ \\
\hline & & Paddy field & $\begin{array}{l}\text { Irrigated paddy field/Fields on hilltops which depend on } \\
\text { rains for water }\end{array}$ \\
\hline & & $\begin{array}{l}\text { Reclaimed farmland of the mining } \\
\text { area }\end{array}$ & Reclaimed dry land/paddy field/vegetable greenhouse \\
\hline & & Vegetable greenhouse landscape & $\begin{array}{l}\text { Simple greenhouse/ Arched steel tube vegetable } \\
\text { greenhouse/Solar greenhouse/The steel structure of } \\
\text { multi-span greenhouse/High-grade multi-span stripping } \\
\text { vegetable greenhouse }\end{array}$ \\
\hline & & Garden landscape & Reclaimed garden of the mining area/Orchard \\
\hline & & Forest landscape & $\begin{array}{l}\text { Natural forestland/Artificial forestland/Reclaimed } \\
\text { forestland of the mining area }\end{array}$ \\
\hline \multirow{3}{*}{$\begin{array}{l}\text { Grassland } \\
\text { landscape }\end{array}$} & $\begin{array}{l}\text { Extremely healthy } \\
\text { grassland landscape }\end{array}$ & $\begin{array}{l}\text { High-quality natural } \\
\text { pasture/Improved } \\
\text { grassland/Artificial } \\
\text { herbage/Reclaimed grassland of } \\
\text { the mining area / Wetland }\end{array}$ & $\begin{array}{l}\text { High quality caragana microphylla/Stipa grandis + } \\
\text { Leymus chinensis/Leymus chinensis/Stipa krylovii roshev } \\
\text { + Leymus chinensis/One or two year cluster }\end{array}$ \\
\hline & $\begin{array}{l}\text { Healthy grassland } \\
\text { landscape }\end{array}$ & $\begin{array}{l}\text { Natural pasture/Improved } \\
\text { grassland/Artificial } \\
\text { herbage/Reclaimed grassland of } \\
\text { the mining area/Wetland }\end{array}$ & $\begin{array}{l}\text { Caragana microphylla/Stipa grandis + Leymus } \\
\text { chinensis/Leymus chinensis/Stipa krylovii roshev + } \\
\text { Leymus chinensis/One or two year cluster/Stipa krylovii } \\
\text { roshev/Splendid achnatherum + Leymus chinensis }\end{array}$ \\
\hline & $\begin{array}{l}\text { Unhealthy grassland } \\
\text { landscape }\end{array}$ & $\begin{array}{l}\text { Mild/Medium/Severe unhealthy } \\
\text { grassland landscape }\end{array}$ & $\begin{array}{l}\text { Salinization/Desertification/Bare rock/Bare land } \\
\text { landscape }\end{array}$ \\
\hline
\end{tabular}


Table 2. Cont

\begin{tabular}{|c|c|c|c|}
\hline Kingdom & Class & Family & Species \\
\hline \multirow{12}{*}{$\begin{array}{l}\text { Network } \\
\text { landscape }\end{array}$} & \multirow{3}{*}{ Water network landscape } & River and channel landscape & Natural/Artificial river/Channel \\
\hline & & Lake landscape & Natural/Artificial lake/Reservoir \\
\hline & & Swag landscape & Natural/Artificial swag \\
\hline & \multirow{2}{*}{ Road network landscape } & Railway network landscape & $\begin{array}{l}\text { High-speed railway/Special railway of the mining } \\
\text { area/Other railways }\end{array}$ \\
\hline & & Road network landscape & Mining special road/Highway/Urban road/Country road \\
\hline & \multirow{2}{*}{ Power network landscape } & $\begin{array}{l}\text { Transmission network of } \\
\text { coal-power bases }\end{array}$ & Ultra-High/Super-high/High/Medium voltage grid \\
\hline & & Other transmission networks & Ultra-high/Super-high/High/Medium voltage grid \\
\hline & \multirow{5}{*}{$\begin{array}{l}\text { Potential landscape } \\
\text { ecological network }\end{array}$} & "Source" landscape & (Extremely) healthy grassland landscape \\
\hline & & “Sink" landscape & Unhealthy mining landscape \\
\hline & & Ecological corridor & $\begin{array}{l}\text { Pattern upgrade function/Patterns control process } \\
\text { ecological corridor }\end{array}$ \\
\hline & & Ecological nodes & First/Second/Third level ecological nodes \\
\hline & & Constructed wetland & First/Second/Third level constructed wetlands \\
\hline
\end{tabular}

Landscape Kingdom. Based on the interference of humans in the natural matrix landscape and the functions of the patches formed after the disturbance, the MCSS is divided into grassland landscape, mining landscape, town landscape, and network landscape. Grassland landscape is a natural or semi-natural matrix landscape, with less human disturbance, maintaining the natural condition mainly used for animal husbandry and agriculture. Its function primarily includes biological production and environmental services. The town landscape is a residential area with a certain scale of industry and commerce. Its main function is cultural support. The mining landscape is based on the development of mineral resources as the main function. Generally speaking, the mining landscape belongs to the industrial and mining storage landscape in the town landscape, but for the purposes and needs of this study, it is upgraded to one of the primary landscapes. The network landscape is a fast channel of material flow, energy flow, and information flow connected by corridors and nodes.

Landscape Class. Based on the status of land cover, land use, and landscape process in the landscape area, the second levels were classified. The mining landscape includes open-pit landscape, dumping landscape, mining industrial square landscape, mining relics landscape, and mining disturbing landscape. The town landscape includes town commercial and residential service landscape, industrial and storage landscape, greenland landscape, and agricultural landscape. The grassland landscape includes extremely healthy grassland landscape, healthy grassland landscape, and unhealthy grassland landscape. The grassland landscape is the matrix landscape of the study area, based on the natural formation, and provides a variety of primary products. The network landscape includes those formed naturally, such as water networks, as well as constructed networks such as roads, railways, and power grids. In addition, the network landscape also includes a potential landscape ecological network.

Landscape Family and Species. Landscape family and species are the more detailed division of the upper landscape types, respectively. In order to highlight the impact of coal resource exploitation on regional landscape ecology and the needs of subsequent research work on the evolution, simulation, planning, and restoration of the mining landscape, it is necessary to take full account of the various ecological effects brought by coal resource exploitation. For example, changes in topography caused by coal mining result in changes in landscape ecology, which will impact the evolution of the landscape. In order to analyze the direct impact of resource development disturbance on the landscape, terrain changes can be included in the classification system, for example, the open-pit landscape is divided into open-pit-slope and open-pit-flat. In addition, it is necessary to set up the unique 
landscape types of MCSS, such as coal gangue dumps, subsided land, ground fissure, thermal power plant, and so on. Landscape family and species are the basic units of classification. These levels need to employ high-resolution remote sensing image mapping. It is mainly applied to fine-scale landscape classification, which can be combined with a digital elevation model and field investigation.

\subsection{Landscape Mapping Results of MCSS}

Landscape mapping based on the LEC system is the basic work for implementing landscape ecological assessment, evolution, planning, and management. On the one hand, it can visually show the spatial distribution of landscape types and comprehensively reflect the relationships between landscape elements. On the other hand, it can test and evaluate the effectiveness of the LEC system. Landscape mapping results of MCSS are shown in Figure 4 . The area and proportion of each landscape type are shown in Table 3.

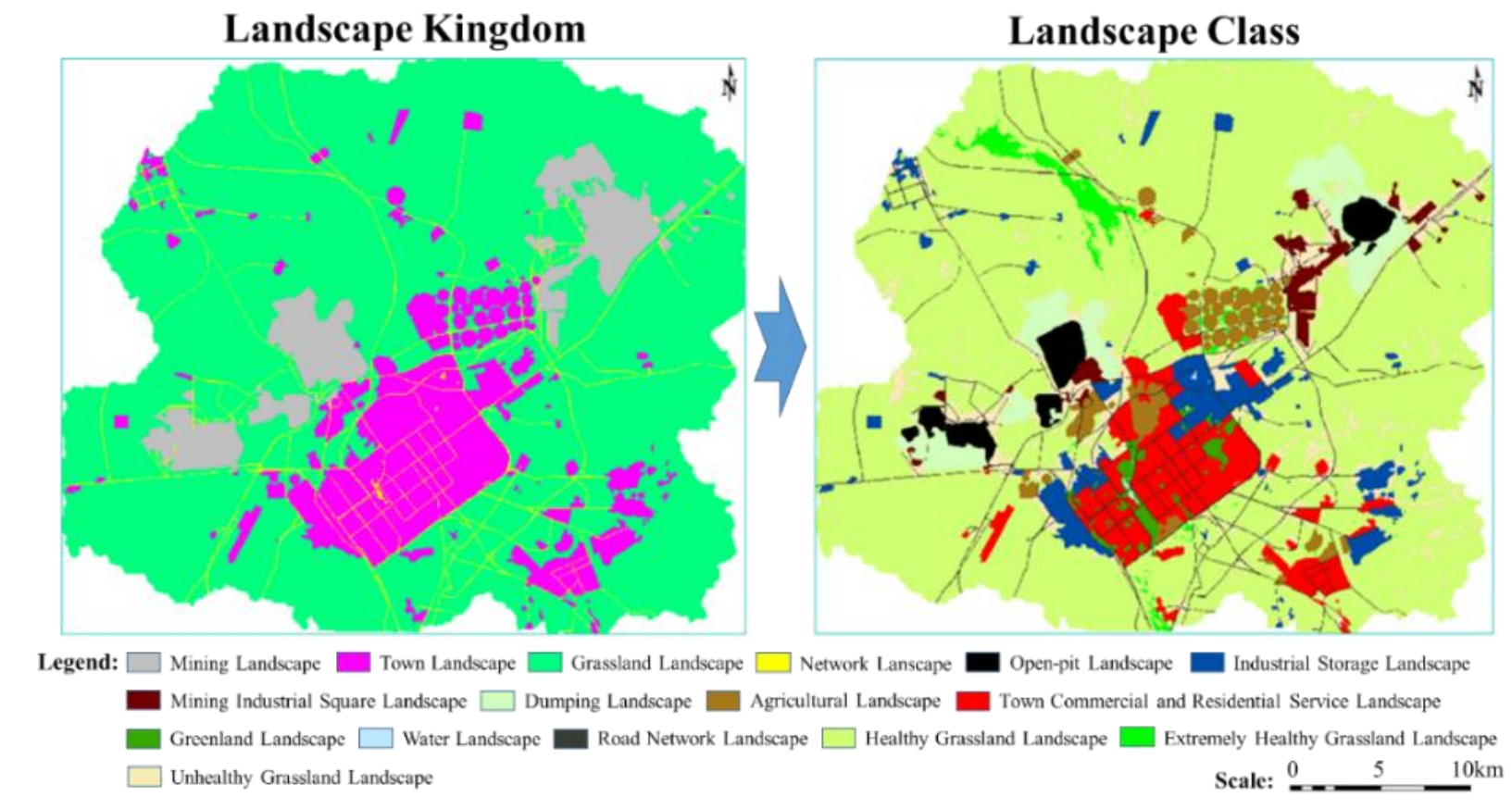

Figure 4. Investigation results of landscape types of MCSS (Remarks: Figure 4 was drawn by the author using the method of support vector machine combined with visual interpretation).

Landscape Kingdom. Grassland landscape accounted for $76.84 \%$ of the total area. Obviously, the grassland is the matrix of the study area. The mining landscape is mainly located in the northern suburbs of Xilinhot City, which is the same as the location of Shengli Coal Field. The Shengli Coalfield is just located in the upwind position of the city, so dust pollution is the key problem to be considered when optimizing the landscape pattern of the study area. The town landscape is embedded in the grassland landscape, and its distribution is more dispersed than the mining landscape. The area of urban landscape ranks second in the four categories of landscape, which is about twice the area of the mining landscape. This also confirms that Xilinhot City is the seat of the Xilingol League government and also the political, economic, cultural, and transportation center of the Xilingol League. Although network landscape only accounts for $2.67 \%$ of the total area, the network landscape is distributed throughout the study area. On the one hand, mining landscape and urban landscape, especially grassland landscape, are divided into patches of different sizes. On the other hand, it is an important channel for various ecological flows. 
Table 3. Area and proportion of each landscape type for the study area in 2017.

\begin{tabular}{|c|c|c|c|c|c|}
\hline \multicolumn{3}{|c|}{ Landscape Kingdom } & \multicolumn{3}{|c|}{ Landscape Class } \\
\hline Types & Areas $\left(\mathrm{km}^{2}\right)$ & Proportion & Types & Areas $\left(\mathrm{km}^{2}\right)$ & Proportion \\
\hline \multirow{3}{*}{ Mining Landscape } & \multirow{3}{*}{71.75} & \multirow{3}{*}{$7.02 \%$} & Open-Pit Landscape & 20.70 & $2.03 \%$ \\
\hline & & & Dumping Landscape & 37.63 & $3.68 \%$ \\
\hline & & & Mining Industrial Square Landscape & 13.42 & $1.31 \%$ \\
\hline \multirow{3}{*}{$\begin{array}{l}\text { Grassland } \\
\text { Landscape }\end{array}$} & \multirow{3}{*}{784.85} & \multirow{3}{*}{$76.84 \%$} & $\begin{array}{l}\text { Extremely Healthy Grassland } \\
\text { Landscape }\end{array}$ & 13.06 & $1.28 \%$ \\
\hline & & & Healthy Grassland Landscape & 713.01 & $69.81 \%$ \\
\hline & & & Unhealthy Grassland Landscape & 58.78 & $5.75 \%$ \\
\hline \multirow{4}{*}{ Town Landscape } & \multirow{4}{*}{137.66} & \multirow{4}{*}{$13.47 \%$} & $\begin{array}{l}\text { Town Commercial and Residential } \\
\text { Service Landscape }\end{array}$ & 63.36 & $6.20 \%$ \\
\hline & & & Industrial and Storage Landscape & 39.04 & $3.82 \%$ \\
\hline & & & Greenland Landscape & 8.11 & $0.79 \%$ \\
\hline & & & Agricultural Landscape & 27.05 & $2.65 \%$ \\
\hline \multirow{2}{*}{$\begin{array}{l}\text { Network } \\
\text { Landscape }\end{array}$} & \multirow{2}{*}{27.22} & \multirow{2}{*}{$2.67 \%$} & Road Network Landscape & 26.67 & $2.61 \%$ \\
\hline & & & Water Network Landscape & 0.55 & $0.05 \%$ \\
\hline Total & 1021.38 & $100 \%$ & Total & 1021.38 & $100 \%$ \\
\hline
\end{tabular}

Landscape Class. The dumping landscape and mining industrial square landscape are mainly distributed around the open-pit landscape, which is determined by the current mining-disposal-overburden integrated open-pit mining model. The area of the dumping landscape is more than the sum of open-pit landscape and mining industrial square landscape, which indicates that the coal enterprises are constantly carrying out ecological restoration while pursuing economic benefits. The town commercial and residential service landscape is mainly distributed in the main urban area of Xilinhot city. Airport, township, cemetery, racecourse, and other town commercial and residential service landscapes are also distributed outside the main urban area. The industrial storage landscape is mainly located in the suburbs. Many industries in Xilinhot city are coal mine-derived industries, such as the coal chemical industry, gangue cement plant, and so on. Therefore, the development of the large-scale coal-power base promotes the development of the local industry. The agricultural landscape is mainly located in the north and northeast of the city. As a semi-arid steppe region, its agricultural landscape area reaches $27.05 \mathrm{~km}^{2}$, indicating that Xilinhot City is a city where agriculture and animal husbandry coexist. The Xilin River passes through the city. A large area of greenland landscape is distributed around Xilin River, which is the urban landscape axis of Xilinhot. However, the area of the greenland landscape only accounts for about $1 / 8$ of the area of town commercial and residential service landscape, which shows that the urban construction of Xilinhot City needs to consider ecological construction more. At the same time, the water landscape only occupies $0.05 \%$ of the total area of the study area, which shows the degree of drought and water shortage. Road network landscape extends in all directions, connecting town commercial and residential services landscape, industrial storage landscape, agricultural landscape, and mining landscape throughout the study area. Extremely healthy grassland landscape is mainly located in the wetland of the Xilin River Basin. The unhealthy grassland landscape is mainly located in the surrounding areas of mining landscape, town commercial and residential service landscape, and industrial storage landscape.

Based on the Landscape Class, this study further drew the map of landscape types evolution in the study area from 2002 to 2017 (Figure 5) [43]. 


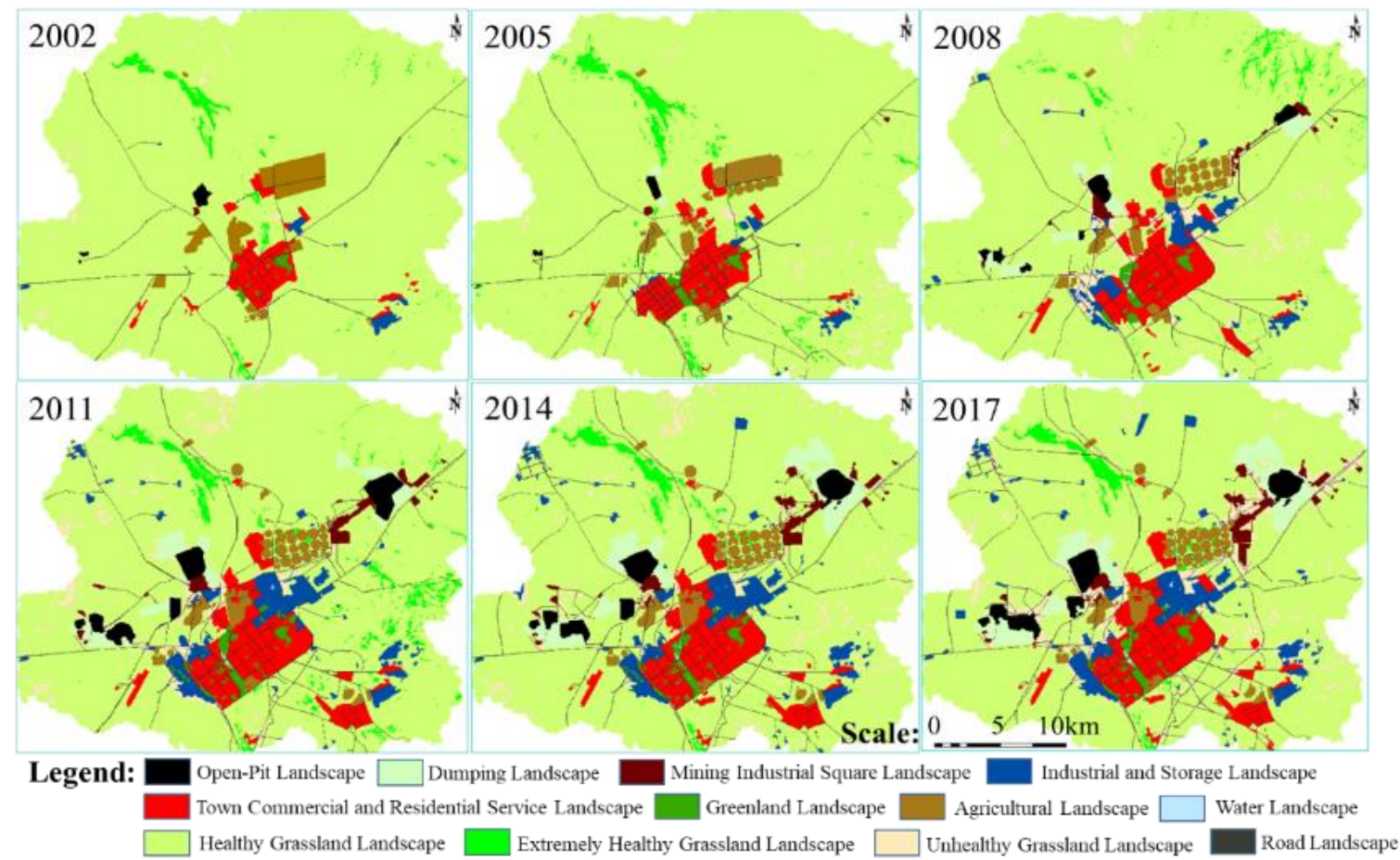

Figure 5. Map of landscape types evolution for research area from 2002 to 2017 (Remarks: Figure 5 was drawn by the author using the method of support vector machine combined with visual interpretation).

\subsection{Analysis on Change Intensity Characteristics of Main Landscape Types in the Study Area}

The period of change can be divided into the four following types: Gentle Expansion Periods (GEP), Intense Expansion Periods (IEP), Gentle Retreat Periods (GRP), and Intense Retreat Periods (IRP). GEP means that the CI is positive, and the absolute value is less than the absolute value of the total CI. IEP means that the CI is positive, and the absolute value is greater than the absolute value of the total CI. GRP means that the CI is negative, and the absolute value is less than the absolute value of the total CI. IRP means that the CI is negative and the absolute value is greater than the absolute value of the total CI. In this study, the total CI refers to the CI from 2002 to 2017.

The CI of the open-pit landscape. According to formula 1, the CI types of the open-pit landscape in 2002-2005, 2005-2008, 2008-2011, 2011-2014, and 2014-2017 are GRP, IEP, IEP, GEP, and GEP, respectively. From 2002 to 2017, the open-pit landscape was generally in a state of expansion, the expansion intensity from 2005 to 2011 was especially intense, and the expansion intensity was relatively gentle after 2011.

The CI of the dumping landscape. The CI types of the dumping landscape in 2002-2005, 2005-2008, 2008-2011, 2011-2014, and 2014-2017 were GEP, IEP, IEP, IEP, and GEP, respectively. From 2002 to 2017, the dumping landscape was generally in a state of expansion, and the type of expansion changed from gentle expansion to drastic expansion and then to a gentle expansion. Different from the open-pit landscape, the period of a dramatic expansion of the dumping landscape lasted from 2005 to 2014, which shows that ecological restoration is accompanied by coal development.

It can be observed from Figure 6, the trend of CI of the mining industrial square landscape and industrial storage landscape is very similar. This is because the main types of industries in Xilinhot are coal deep processing, thermal power generation, cement (the raw material is coal gangue), and other industries that are highly related to the coal industry. Therefore, the development of coal drives the development of the regional industry. The expansion intensity of the town commercial and residential service landscape is gradually decreasing. The main reason is that Xilinhot City is located at the northern border of China, with a small population, slow growth, and insufficient motivation for urban expansion. The expansion of the road network landscape is fluctuating, reaching its peak in 2008-2011. 
The CI types of grassland landscape in 2002-2005, 2005-2008, 2008-2011, 2011-2014, and 2014-2017 were GRP, IRP, IRP, GRP, and GRP, respectively. From 2002 to 2017, the grassland landscape was the only landscape that was always in a state of retreat, and it was also the only type of landscape that experienced a period of severe retreat. From 2002 to 2017, the unhealthy grassland landscape was always in a state of expansion, especially in 2005-2008 and 2014-2017 where there were two peaks. Therefore, it is imperative to protect grassland.

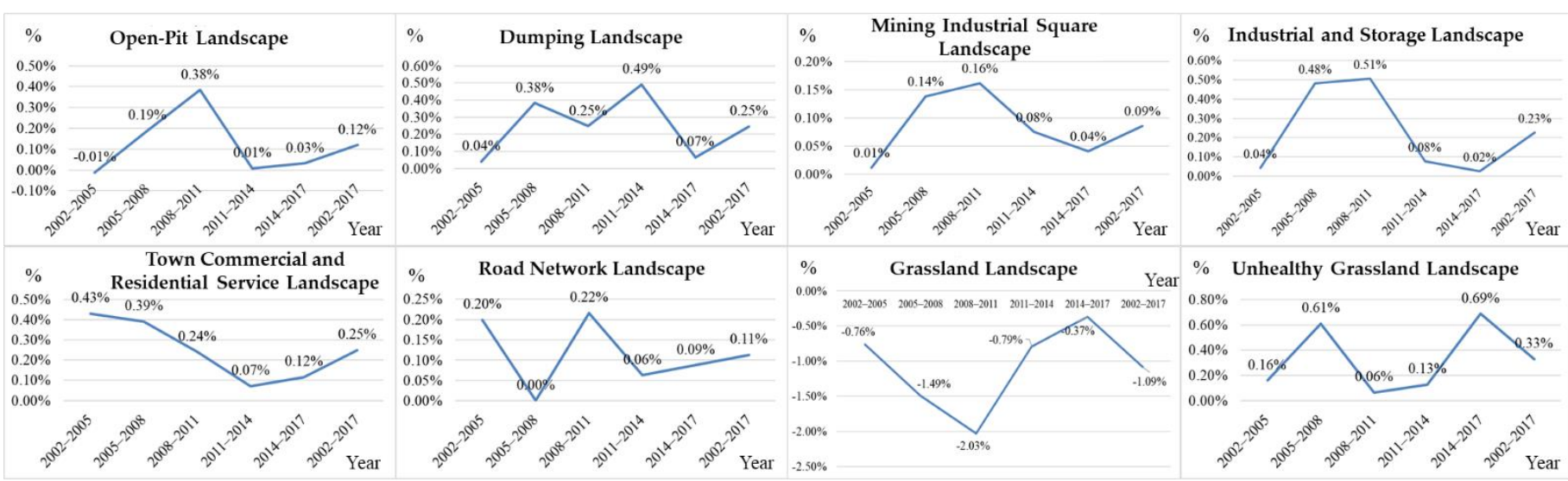

Figure 6. Change intensity of main landscape types (Remarks: Figure 6 was drawn by the author).

\subsection{Dynamic Degree of Spatial Change of Landscape Types in the Study Area}

It can be observed from Table 4 that the dynamic degree of spatial change of unhealthy grassland landscape is always the highest at each research stage. The reason is that the unhealthy grassland landscape is mainly located in the surrounding areas of the artificial landscape such as mining landscape, industrial storage landscape, town commercial and residential service landscape, and road network landscape. The expansion of artificial landscape occupied unhealthy grassland landscape, and unhealthy grassland landscape occupied healthy grassland landscape again. This is a typical landscape evolution model of "human advance and grassland retreat". The dynamic degree of the spatial change of grassland landscape is the most stable and always between $6 \%$ and $11 \%$. This is because the grassland landscape has a large base. Although various artificial landscapes have been occupying the grassland landscape, their proportion is still small compared with the total grassland landscape. The dynamic degree of spatial change of open-pit landscape, dumping landscape, mining industrial square landscape, industrial storage landscape, and road network landscape exceeded 20\% in 2002-2005, 2005-2008, and 2008-2011, and the activity degree was very high. These three stages are the powerful embodiment of Xilinhot's industrial development. The dynamic degree of spatial change of town commercial and residential service landscape was less than $20 \%$ in each stage, and the overall trend was decreasing. At the same time, the dynamic degree of spatial change of all kinds of artificial landscapes also showed an overall decreasing trend. Until 2014-2017, the dynamic degree of spatial change of all kinds of the artificial landscape was less than $12 \%$, and the dynamic degree of spatial change of town commercial and residential service landscape was even as low as $2.72 \%$. It can be observed that the intensity of human occupation of grassland was decreasing [43]. 
Table 4. Dynamic degree of spatial change of landscape types at different research stages.

\begin{tabular}{|c|c|c|c|c|c|c|c|c|}
\hline $\begin{array}{c}\text { Year } \\
\text { Period }\end{array}$ & $\begin{array}{l}\text { Open-Pit } \\
\text { Landscape }\end{array}$ & $\begin{array}{l}\text { Dumping } \\
\text { Landscape }\end{array}$ & $\begin{array}{l}\text { Mining Industrial } \\
\text { Square Landscape }\end{array}$ & $\begin{array}{l}\text { Town Commercial } \\
\text { and Residential } \\
\text { Service Landscape }\end{array}$ & $\begin{array}{l}\text { Industrial } \\
\text { and Storage } \\
\text { Landscape }\end{array}$ & $\begin{array}{c}\text { Road } \\
\text { Network } \\
\text { Landscape }\end{array}$ & $\begin{array}{l}\text { Grassland } \\
\text { Landscape }\end{array}$ & $\begin{array}{l}\text { Unhealthy } \\
\text { Grassland } \\
\text { Landscape }\end{array}$ \\
\hline 02-05 & $34.18 \%$ & $33.33 \%$ & $18.27 \%$ & $18.25 \%$ & $24.00 \%$ & $32.29 \%$ & $6.59 \%$ & $46.42 \%$ \\
\hline 05-08 & $26.59 \%$ & $30.43 \%$ & $29.70 \%$ & $14.41 \%$ & $24.56 \%$ & $22.24 \%$ & $10.52 \%$ & $38.98 \%$ \\
\hline 08-11 & $23.81 \%$ & $24.89 \%$ & $27.21 \%$ & $15.53 \%$ & $24.79 \%$ & $33.94 \%$ & $9.05 \%$ & $49.24 \%$ \\
\hline $11-14$ & $18.86 \%$ & $18.60 \%$ & $12.77 \%$ & $1.53 \%$ & $4.64 \%$ & $6.93 \%$ & $6.33 \%$ & $38.26 \%$ \\
\hline $14-17$ & $11.41 \%$ & $4.46 \%$ & $6.65 \%$ & $2.72 \%$ & $4.98 \%$ & $5.06 \%$ & $6.37 \%$ & $35.27 \%$ \\
\hline
\end{tabular}

\section{Discussion}

\subsection{Characteristics of LEC System of MCSS}

Due to the uneven distribution of resources in China, coal resources are mainly distributed in the western and northern arid/semi-arid regions, whereas energy demand is distributed in the eastern and southern regions. Large-scale, long-distance coal transportation has seriously increased manpower, material, financial, and environmental costs. Converting transportation coal into transportation power is an effective method to solving this contradiction by building the coal-power base. The idea of a coal-power base refers to the integration of coal reserves and production with the planned construction of power plants for external transmission [44]. The LEC of MCSS is the result of abstracting all of the attributes and characteristics of complex coal mining and electric power development systems, and it is a rational simplification process. The occurrence mechanism, ecological processes, and classification principle of MCSS landscape ecology have their characteristics.

Characteristic of hierarchy. Any biological system has a hierarchical structure. MCSS is a complex and orderly system structure composed of several units. Complex systems often have hierarchical forms. A complex system consists of interrelated sub-systems [45]. High-level classification requires a broad and comprehensive generalization. Low-level classification needs to determine the differences between small-scale landscape units and can fully highlight the characteristics of each landscape element. In the MCSS landscape, ecological gradation contains non-nested characteristics. For example, mining and nonmining areas both have office landscapes. The hierarchical system has a vertical structure and a horizontal structure. For example, the "Mining Landscape $\rightarrow$ Mining Industrial Square Landscape $\rightarrow$ Thermal Power Plant "belongs to the vertical structure, and "Mineral Geological Relics-Mining Production Relics-Mining Relics for Social Life" belongs to the horizontal structure.

Characteristic of scale. The time-space scales are included in the ecological process of any landscape [46]. At different time-spatial scales, the same landscape will simultaneously show homogeneity and heterogeneity. The level of landscape ecology and hierarchy is also dependent on the size of the spatial scale, so the study of LEC must take into account the role of scale. The ecological scale has three aspects: dimension, category, and composition. The dimensions include time scales, spatial scales, and organizational scales. For MCSS, the time scale can take into account the whole life cycle of the mining area, the spatial scale is the mining city, and the organization scale is the landscape scale.

Characteristic of landscape processes. Landscape processes are within the scope of the time-space scales, operating in the landscape, showing the interrelated and interdependent interactions among the landscape elements, emphasizing the occurrence and development of events or phenomena, and are important in affecting the variation of landscape pattern. Landscape-scale processes are driven by many elements and are associated with other processes in more restricted areas. The overall landscape process is the result of the interaction of both natural and man-made factors, and with economic development, technological progress, and population growth, the impact of human factors is becoming bigger and bigger [47]. In the prehistoric period, primitive human beings lived on the grassland by hunting, survived equally with other animals, and were not the dominant species that affected the landscape ecology of the area. With the development of human civilization and its productive forces, humans learned to domesticate grazing animals, and nomadic 
people were born. Commodity trading and political demand increased as urban landscapes continued to grow and developed in the grasslands. By the late 18th century, the industrial revolution made coal the most extensively used industrial production fuel, and mining landscapes were born.

Characteristic of patch-corridor-matrix. The patch-corridor-matrix landscape spatial mosaic pattern laid the foundation for the study of the combination of landscape areas of MCSS. The matrix is the most widely distributed background structure in the landscape. The mining areas are added to the native grassland as the matrix. The introduction of an artificial patch into the grassland matrix formed the urban landscape patch, and the urban landscape patch originated from the human nature of the natural ecosystem. The obvious features are the following: (1) The ecological structure in the settlements depends on the biological type that replaces the natural ecosystem; and (2) the persistence of highly humanized settlements depends partly on the extent and permanence of human management. The mining landscape is a disturbance patch formed by high-intensity disturbance over a period, which is different from the matrix of grassland and town landscape [48]. Town and mining landscape patches are different from the grassland matrix in appearance or nature and have some internal heterogeneity. In addition, MCSS has rivers and other environmental resources corridors, coal transportation corridors and other disturbance corridors, natural grasslands remaining along railways and other remnant corridors, shelters, and other planting corridors. On the one hand, the corridors are the channels for the transmission and migration of energy, matter, and species, while they are also are obstacles for the movement of species in the grassland matrix on the other hand. Thus, it is necessary to set up a passage through the corridors for these species (Figure 3f).

Characteristic of the network. Corridors intersect one another to form a network that complicates the interaction of corridors with patches and matrix. The function of the network is similar to the corridor, but it is more extensive and close to the matrix [49]. The landscape ecological network connects the different landscape components effectively, serving as a rapid channel of material flow, energy flow, and information flow. In the mining city, a variety of road networks, railway networks, water networks, and highvoltage power grid networks may be arranged in a crisscross pattern, these networks may have similarities in structure and are closely linked with the mining city, but their function is very different.

Characteristic of multiple planning integration. The particularity of the LEC in the mining area, as reflected in the characteristics of the dynamic nature of mining development should be considered fully. That is, in the classification, not only the current stable subsidence land, coal gangue dumps, coal fly ash dumps, open-pit mine, and dumping site and other landscape patch types should be considered but also the landscape patch types that form in the near future. Mining landscapes are different from closed systems, and their ecosystems are always open. Due to the constant input and output of material flow, energy flow, information flow, and so on, the boundary of the internal patch in the mining landscape has always changed. So we should consider the United States Geological Survey land cover classification system [50], land use planning, mineral resources planning, reclamation planning for mining areas, mine environmental protection, comprehensive treatment plans, and other planning or programs.

Characteristic of complexity. A mining city is a regional synthesis composed of various landscape elements. The formation of a mining city is the result of the combined effect of a variety of factors; thus, any classification should reflect the characteristics of the complex. Comprehensive inspection can be conducted from the landscape ecosystem spatial form, spatial heterogeneity combination, occurrence processes, and ecological functions of the four aspects of the characteristics. The LEC study of MCSS must take into account all the factors that affect the formation of the landscape. Only in this manner can we have a macro grasp of the landscape ecology in the study area, avoid the omission of some landscape elements, and cause an unreasonable construction of the classification system. 
Characteristic of the combination of structure and function. The structure is the basis of function. The function is the reflection of structure. The mining city landscape ecosystem is composed of multiple interrelated elements that are mutually restrained, with an orderly internal structure of the complex geography. The LEC includes unit determination and type merging. The unit determination is based on the functional relationships, and type merging takes the spatial form as the index. LEC is focused on the function that inheres to the structure in order to divide landscape ecosystem types. Through the establishment of the LEC system, we fully reflect the spatial differentiation and organizational association of certain regional landscapes, thereby revealing their spatial structure and ecological function.

Characteristic of the combination of the human-dominated and natural landscape. Highintensity coal mining and power development are the main factors in the change associated with mining city, which has a profound impact on the natural landscape, and the town landscape similarly affects the grassland matrix. For millions of years, there has been almost no type of landscape that is completely unaffected by human activities in the semiarid steppe. Therefore, the LEC of MCSS has the characteristics of human dominance. In addition, the landscape is a regional complex synthesis of the regional natural environment and human social interference. MCSS formation and development factors are complex and diverse, while vegetation and hydrology and other natural elements can directly reflect the different characteristics of different landscape types. They are important indicators for the classification of landscape ecosystem types [51]. Human dominance is mainly embodied in the landscape functional classification, and natural representation is mainly embodied in the landscape structural classification. The division of landscape ecological types of MCSS needs to follow the characteristic of the combination of human-dominated and natural landscapes.

Characteristic of highlighted features. Even for the study of the same area of landscape ecology, the focus of research is very different for different research purposes, which will result in different classification results. Therefore, LEC needs to highlight the research focus. For example, in the study of town landscape, mining landscape can only be used as a part of the industrial and mining storage landscape, but mining landscape is the most important in this study. In addition, we should pay attention to the process of the impact of mining on regional landscape ecology and take the human activities and the interference factors into account.

\subsection{Verification of LEC System of MCSS}

The landscape is a product of interactions between humans and nature that bring multiple characteristics to discrete geographic settings [52]. Landscapes are complex, spatially heterogeneous systems with many properties and values [12]. Thus, each landscape type should have different attributes. In this study, NDVI and ESF were used to verify the LEC system of MCSS.

NDVI has a strong correlation with photosynthesis and biomass. Historically, NDVI has been used as a substitute for ecosystem productivity or general ecosystem energy and has been widely used in many disciplines [53]. It can be observed from Figure 7 that the extremely healthy grassland landscape has the highest NDVI. The extremely healthy grassland landscape is mainly distributed in the wetland of the Xilin River Basin with the densest vegetation. The low NDVI value of unhealthy grassland landscape is mainly caused by desertification, salinization, soil erosion, overgrazing, and other factors (Figure 8). The NDVI of agricultural landscape ranks second, and the agricultural landscape of Xilinhot City is dominated by large farms (Figure 8). The Greenland landscape of Xilinhot City is mainly urban park greenland, and its NDVI is also high (Figure 8). The NDVI of the water landscape is the lowest but not zero. This is because a small amount of aquatic plants in the water has also been monitored by remote sensing. As shown in Figure 3a, there will be a small amount of vegetation on the side slope (including flat plate and slope) of the open-pit; thus, the NDVI is not zero. The mining industrial square landscape, industrial 
storage landscape, road network landscape, and town commercial and residential service landscape are mainly hardened cement, but there will be a small number of green belts; thus, their NDVI is low but not zero. In particular, the Chinese government ordered mining companies to build garden-style mines; thus, the NDVI values of the mining industrial square landscape and the town industrial storage landscape are relatively close. From the average value of NDVI of each landscape type, it is consistent with the actual situation.

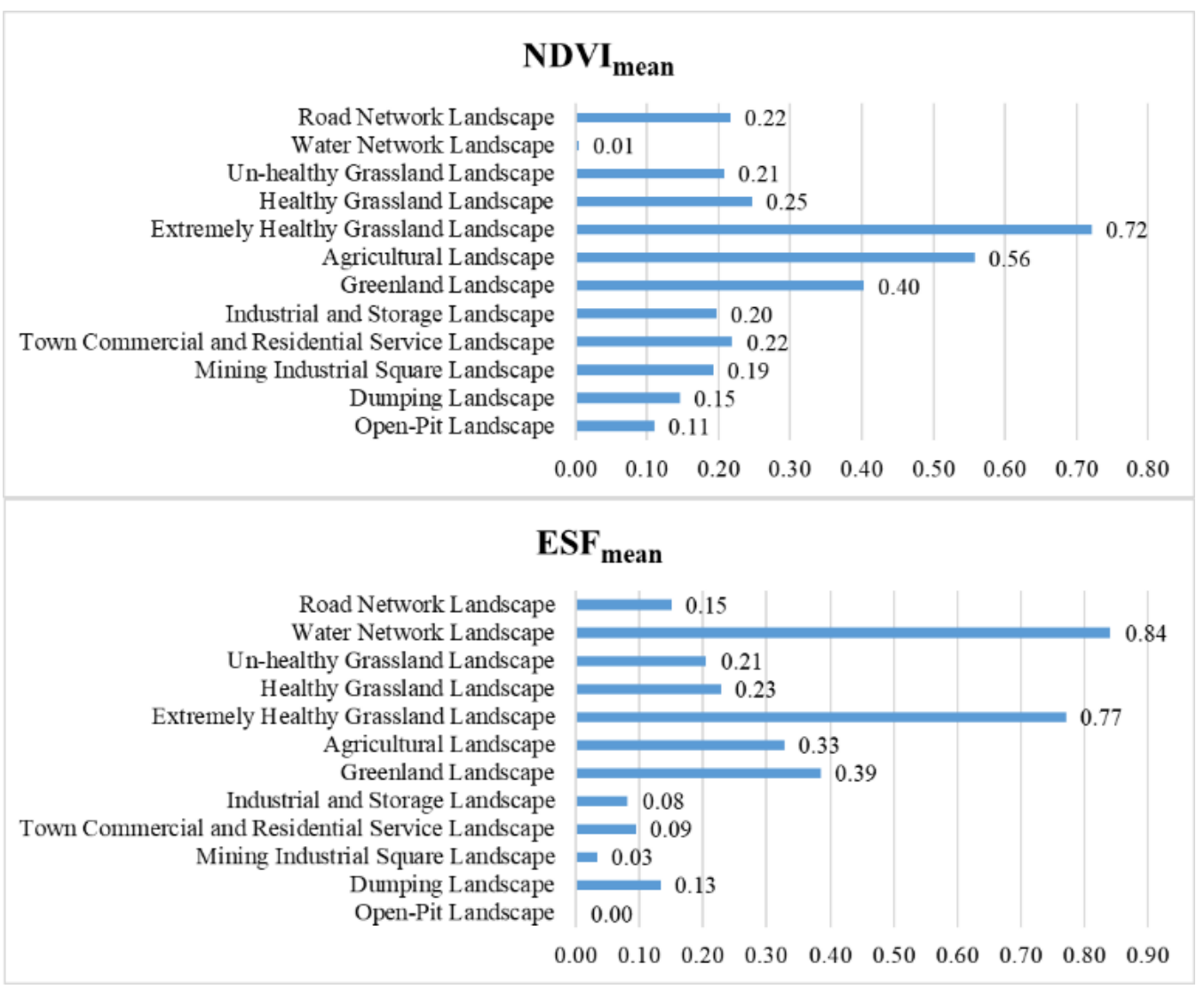

Figure 7. Average of NDVI and ESF for each landscape type in studied area (Remarks: Figure 7 was drawn by the author).

The MCSS is a spatial mosaic of landscape ecosystems with different functional types, and its overall function is the coupling of various heterogeneous functions. LEC is a functional division of landscape types [51]. It can be observed from Figure 7 that the ESF of the water landscape is the highest. The main ecological problem in the study area is drought and water shortage. In the semi-arid steppe, the water landscape is a natural "source" landscape, an important natural habitat of species, the origin of high-quality ecological flow, and an important guarantee of regional ecological security. It has many functions, such as protecting biodiversity, conserving water, filtering pollutants, and so on. The extremely healthy grassland landscape also has the function of a "source" landscape. Extremely healthy grassland landscape is mainly distributed around the water landscape, and it continuously provides high-quality ecosystem services for the surrounding landscape together with water landscape. Although the area of extremely healthy grassland landscape is small, accounting for only $1.28 \%$ of the total area of the study area, it plays a crucial role in improving the overall landscape function of the semi-arid grassland. Greenland landscape mainly provides cultural service functions, and the agricultural landscape mainly provides production functions. The ESF values of these two landscapes are also higher. The ESF value of the open-pit landscape is zero. The open-pit landscape is a "sink" landscape. Highintensity surface coal mining has caused the destruction of large areas of surface native vegetation, and wind erosion further accelerates the desertification of exposed soil and 
rock formations and even forms mobile dunes and further deteriorates into deserts [54]. Therefore, the open-pit landscape needs to focus on the implementation of landscape engineering restoration.

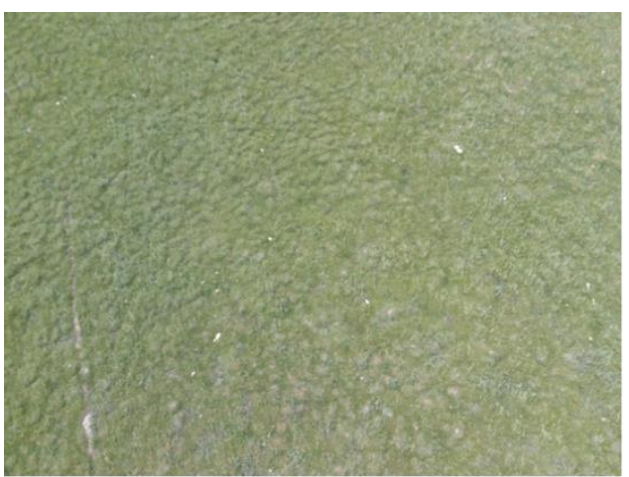

(a)

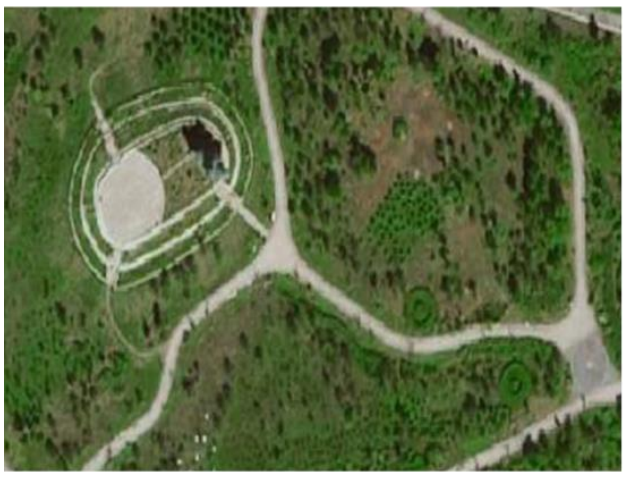

(c)

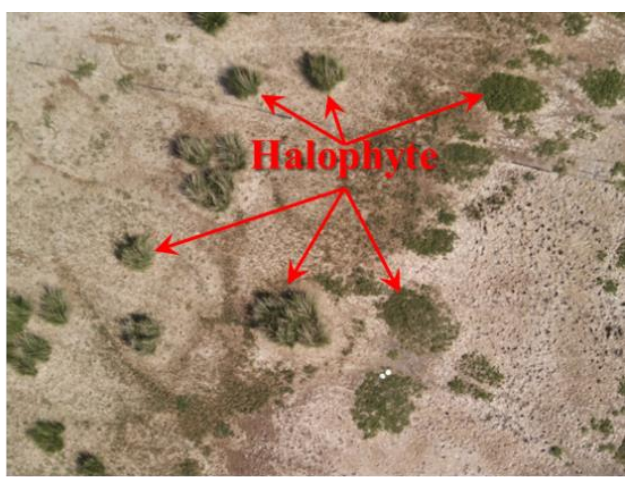

(b)

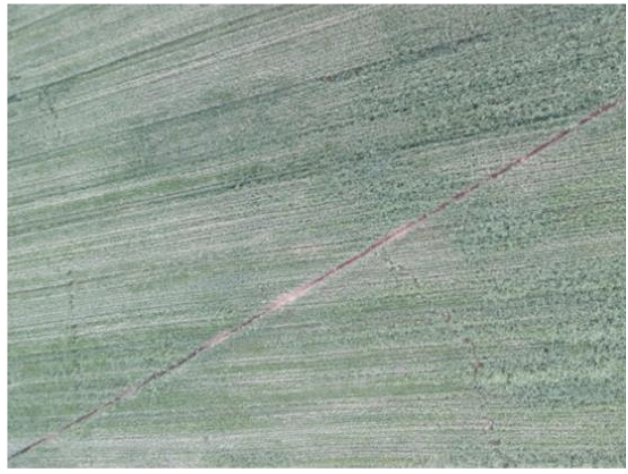

(d)

Figure 8. Photogrammetric images of Xilinguole Grassland taken by the author using unmanned aerial vehicle: (a) Healthy Grassland Landscape; (b) Un-healthy Grassland Landscape; (c) Greenland Landscape; (d) Agricultural Landscape.

The NDVI and ESF of each landscape type in the study area have obvious heterogeneity, which is consistent with the actual situation. Therefore, the LEC system of MCSS proposed in this study is accurate and feasible.

\subsection{Limitations and Uncertainties}

The LEC system constructed in this study fully considers differences in landscape pattern, function, process, and grade. Planning needs a LEC system, which is consistent and reflects the natural patterns, the potential capacity and the limits of natural units, and the history of human use [55]. To some extent, it is a subjective process. We hope that the LEC system constructed by this research can provide theoretical support for decision-makers, government, engineering construction personnel, and other researchers [56]. Each landscape patch unit is a discrete system generated by grid and geology, geomorphology, soil, vegetation, climate, wildlife, water, man, and many other factors [57]. Not all landscapes can be (easily) decomposed into a set of structural-functional units that can be clearly and unambiguously delineated and linked to explanatory conceptual models [58]. Moreover, any ecosystem is a complex system that is constantly changing, and the ecological attributes and boundaries of any landscape patches have the potential for change and may even produce new landscape types. Therefore, the dynamic changes of regional landscapes should be taken into full consideration, and the study of LEC needs to be improved and adjusted constantly. 


\section{Conclusions}

This study constructed a LEC system of MCSS, including 4 types of landscape kingdom, 16 types of landscape class, 62 types of landscape family, and more than 200 types of landscape species. The Landsat images of the study area were used to map the landscape types by using the landscape kingdom and the landscape class, and the results of the landscape survey and classification were analyzed in detail. By studying the landscape types evolution, it is found that both the open-pit landscape and the dumping landscape are constantly expanding, and ecological restoration is accompanied by coal development. The trend of CI of mining industrial square landscape and industrial storage landscape was very similar. The development of coal has driven the development of the regional industry. The expansion intensity of the town commercial and residential service landscape was gradually decreasing, and the motivation for town expansion is insufficient. The dynamic degree of spatial change of unhealthy grassland landscape was always the highest in each research stage. The research area was a typical landscape evolution mode of "human advance and grassland retreat". However, the intensity of humans occupying grassland was decreasing.

Author Contributions: Z.W. conceived and performed the research; S.L. helped to analyze the data; Z.W. and Q.Y. provided fund support and conceived guidance; Q.L. and Q.Y. helped revise the paper; $Z$.W. wrote the paper. All authors have read and agreed to the published version of the manuscript.

Funding: This research is supported by "the Fundamental Research Funds for the Central Universities of China University of Mining and Technology 2021QN1058".

Institutional Review Board Statement: Not applicable.

Informed Consent Statement: Not applicable.

Data Availability Statement: Data is contained within the article.

Acknowledgments: China National Key R\&D and Design Project 2016YFC0501107 and Key R\&D plan of Inner Mongolia Autonomous Region of China 2060399-273.

Conflicts of Interest: The authors declare no conflict of interest.

\section{References}

1. Ottmar, E. King Coal and the queen of subsidies. Science 2015, 349, 1286-1287.

2. Bian, Z. Introduction of Mine Ecology; Coal Industry Publishing House: Beijing, China, 2015.

3. Fu, B. Editorial: Blue Skies for China. Science 2008, 321, 611. [CrossRef] [PubMed]

4. Han, X. Mechanisms for Maintaining Inner Mongolian Grassland Ecosystems; China Agricultural University Press: Beijing, China, 2012.

5. Chen, Q.; Hooper, D.U.; Hui, L.; Xiao, Y.G.; Fei, P.; Hong, W.; Dittert, K.; Shan, L. Effects of resource addition on recovery of production and plant functional composition in degraded semiarid grasslands. Oecologia 2017, 184, 13-24. [CrossRef]

6. Исаченко, А.Г. Landscape Science: Theoretical Foundations and Logical Mathematical Methods; Commercial Press: Beijing, China, 1992.

7. Forman, R.T.; Turner, M.G. Landscape Ecology; John Wile \& Sons: New York, NY, USA, 1986.

8. Westerveld, W.G.; Pedroli, G.B.M.; Broek, M.V.D.; Spoek, J.M. Classification in landscape ecology: An experimental study. Catena 1984, 11, 51-63. [CrossRef]

9. Carlier, J.; Doyle, M.; Finn, J.A.; Ó hUallacháin, D.; Moran, J. A landscape classification map of Ireland and its potential use in national land use monitoring. J. Environ. Manag. 2021, 289, 112498. [CrossRef] [PubMed]

10. Rok Ciglič, D.P. A method for evaluating raster data layers according to landscape classification scale. Ecol. Inform. 2017, 39, 45-55. [CrossRef]

11. Blasi, C.; Capotorti, G.; Copiz, R.; Guida, D.; Mollo, B.; Smiraglia, D.; Zavattero, L. Classification and mapping of the ecoregions of Italy. Plant. Biosyst. 2014, 148, 1255-1345. [CrossRef]

12. Mücher, C.A.; Klijn, J.A.; Wascher, D.M.; Schaminée, J.H. A new European Landscape Classification (LANMAP): A transparent, flexible and user-oriented methodology to distinguish landscapes. Ecol. Indic. 2010, 10, 87-103. [CrossRef]

13. Duning, X. Ecological Principles of Landscape Classification and Evaluation. J. Appl. Ecol. 1998, 9, $217-221$.

14. Wang, Y. Theoretical Methods of Landscape Ecological Classification. J. Appl. Ecol. 1996, 7, 121-126.

15. Cheng, W. A Brief Discussion on Landscape Ecological Classification and Mapping. J. Earth Inf. Sci. 2002, 4, 61-65.

16. Zhou, H. A Preliminary Study on Landscape Classification of the Northern Xinjiang Region-A Case Study of Shawan County. Chin. J. Ecol. 1999, 18, 69-72.

17. Guo, L. Study on Landscape Pattern and Ecological Security of Mount Tai; China Environmental Science Press: Beijing, China, 2008. 
18. Li, Z.; Liu, L.; Xie, H. Methodology of Rural Landscape Classification: A Case Study in Baijiatuan Village, Haidian District, Beijing. Resour. Sci. 2005, 27, 167-173.

19. Shi, Q.D.; Wang, Z.; He, L.M.; Shi, Q.S.; Anayeti, A.; Liu, M.; Chang, S.L. Landscape classification system based on climate, landform, ecosystem: A case study of Xinjiang area. Acta Ecol. Sin. 2014, 34, 3359-3367.

20. Qian, Y.G.; Zhou, W.Q.; Li, W.F.; Han, L.J. A hierarchical landscape classification system for urban regions with high-resolution remote sensing image. Acta Ecol. Sin. 2015, 35, 5207-5214.

21. Luan, Q.; Li, B.; Zhang, X. Urban landscape classification system under influences of atmospheric environment: A case study in Beijing. Chin. J. Ecol. 2019, 38, 1482-1490.

22. Li, G.; Zhang, B. Identification of landscape character types for trans-regional integration in the Wuling Mountain multi-ethnic area of southwest China. Landsc. Urban. Plan. 2017, 162, 25-35. [CrossRef]

23. Han, W. Change of Land Use and Landscape Pattern in Pingshuo Open Coal Mines Based on the 3S Technology. China Land Sci. 2012, 26, 60-65.

24. Hendrychová, M.; Kabrna, M. An analysis of 200-year-long changes in a landscape affected by large-scale surface coal mining: History, present and future. Appl. Geogr. 2016, 74, 151-159. [CrossRef]

25. He, R.; Hu, Z.; Wei, Z.; Jiang, J. In Discussion on Some Problems of Landscape Planning in Coal Mine Area; Proceedings of the 6th Youth Science and Technology Symposium of China Coal Society; Coal Industry Publishing House: Beijing, China, 2000.

26. Wang, Y.; Dawson, R.; Han, D.; Peng, J.; Liu, Z.; Ding, Y. Landscape ecological planning and design of degraded mining land. Land Degrad. Dev. 2001, 12,449-459. [CrossRef]

27. Wang, X.; Han, B.; Wang, Y.; Du, P.; Sun, J. Landscape Eco-Classification in Mining Area Based on RS. J. Liaoning Tech. Univ. 2007, 26, 776-779.

28. Zhang, J.; Fu, M.; Hassani, F.P.; Hui, Z.; Geng, Y.; Bai, Z. Land use-based landscape planning and restoration in mine closure areas. Environ. Manag. 2011, 47, 739-750. [CrossRef] [PubMed]

29. Wenbin, G.; Chunhua, X.; Keming, M.; Jianzhi, N.; Yutao, Z.; Xilin, W. A vital method for constructing regional ecological security pattern: Landscape ecological restoration and rehabilitation. Acta Ecol. Sin. 2003, 23, 64-73.

30. Steenberg, J.W.N.; Millward, A.A.; Duinker, P.N.; Nowak, D.J.; Robinson, P.J. Neighbourhood-scale urban forest ecosystem classification. J. Environ. Manag. 2015, 163, 134-145. [CrossRef]

31. Sterling, S.M.; Ducharne, A.; Polcher, J. The impact of global land-cover change on the terrestrial water cycle. Nat. Clim. Chang. 2013, 3, 385. [CrossRef]

32. Mooney, H.A.; Duraiappah, A.; Larigauderie, A. Evolution of natural and social science interactions in global change research programs. Proc. Natl. Acad. Sci. USA 2013, 110 (Suppl. S1), 3665-3672. [CrossRef]

33. Kobayashi, H.; Watando, H.; Kakimoto, M. A global extent site-level analysis of land cover and protected area overlap with mining activities as an indicator of biodiversity pressure. J. Clean. Prod. 2014, 84, 459-468. [CrossRef]

34. Zhang, Z.; Wu, C.F.; Tan, R. Application of ecosystem service value in land use change research: Bottlenecks and prospects. $J$. Appl. Ecol. 2013, 24, 556-562.

35. Larondelle, N.; Haase, D. Valuing post-mining landscapes using an ecosystem services approach-An example from Germany. Ecol. Indic. 2012, 18, 567-574. [CrossRef]

36. Sonter, L.J.; Moran, C.J.; Barrett, D.J.; Soares-Filho, B.S. Processes of land use change in mining regions. J. Clean. Prod. 2014, 84, 494-501. [CrossRef]

37. Rouse, J.W.; Haas, R.H.; Schell, J.A.; Deering, D.W. Monitoring Vegetation Systems in the Great Plains with Erts. Nasa Spec. Publ. 1974, 351, 309.

38. Wu, Z.; Lei, S.; He, B.J.; Bian, Z.; Wang, Y.; Lu, Q.; Peng, S.; Duo, L. Assessment of Landscape Ecological Health: A Case Study of a Mining City in a Semi-Arid Steppe. Int. J. Environ. Res. Public Health 2019, 16, 752. [CrossRef]

39. Wu, Z. Study on Landscape Pattern Optimization of Large-Scale Surface Coal Base in Semi-Arid Steppe Based on $3 S$ Integrated Technology. Ph.D. Thesis, China University of Mining and Technology, Xuzhou, China, 2020.

40. Du, J.; Du, X. Mining Science; China University of Mining and Technology Press: Xuzhou, China, 2014.

41. Cao, Y.G.; Cheng, Y.; Bai, Z.K. The Changes of Landscape Structure and the Principes of Land Reclamation in the Antaibao Opencast Area. Resour. Ind. 2006, 8, 7-11.

42. Department of Geological Environment, Ministry of Land and Resources of the People's Republic of China. China National Mine Park Construction Work Guide; China Land Press: Beijing, China, 2007.

43. Wu, Z.; Lei, S.; Lu, Q.; Bian, Z. Impacts of Large-Scale Open-Pit Coal Base on the Landscape Ecological Health of Semi-Arid Grasslands. Remote Sens. 2019, 11, 1820. [CrossRef]

44. Zhou, Z.D.; Wang, C.X.; Fu, X.; Quan, Y.; Wei, D.; Wang, Y.; Gao, Y.; Li, S.Y.; Wu, G. Evaluation Index System on Ecological Effect of National Large-Scale Coal-Fired Power Base Based on the DPSIR Conceptual Model. Acta Ecol. Sin. 2014, 1, $2830-2836$.

45. Simon, H.A. The Architecture of Complexity. In Facets of Systems Science; Springer: Boston, MA, USA, 1991.

46. Wiens, J.A. Spatial Scaling in Ecology. Funct. Ecol. 1989, 3, 385-397. [CrossRef]

47. Yu, X.; Niu, J.; Guan, W.; Feng, Z. Landscape Ecology; Higher Education Press: Beijing, China, 2006.

48. Zhang, N. Landscape Ecology; Science Press: Beijing, China, 2014.

49. Wu, J. Landscape Ecology_Pattern, Process, Scale and Hierarchy; Higher Education Press: Beijing, China, 2007. 
50. Anderson, J.R. A Land Use and Land Cover Classification System for Use with Remote Sensor Data; US Government Printing Office: Washington, DC, USA, 1976; Volume 964.

51. Fu, B.J.; Chen, L.D.; Ma, K.M.; Wang, Y.L. Principles and Applications of Landscape Ecology; Science Press: Beijing, China, 2011.

52. Atik, M.; Işıklı, R.C.; Ortaçeşme, V.; Yıldırım, E. Exploring a combination of objective and subjective assessment in landscape classification: Side case from Turkey. Appl. Geogr. 2017, 83, 130-140. [CrossRef]

53. Phillips, L.B.; Hansen, A.J.; Flather, C.H. Evaluating the species energy relationship with the newest measures of ecosystem energy: NDVI versus MODIS primary production. Remote Sens. Environ. 2008, 112, 3538-3549. [CrossRef]

54. Li, N.; Yan, C.Z.; Xie, J.L. Remote sensing monitoring recent rapid increase of coal mining activity of an important energy base in northern China, a case study of Mu Us Sandy Land. Resour. Conserv. Recycl. 2015, 94, 129-135. [CrossRef]

55. Haase, G. Medium scale landscape classification in the German Democratic Republic. Landsc. Ecol. 1989, 3, 29-41. [CrossRef]

56. Meng, W.; Yue, C.; Lv, Y.; Kai, Y. Neighbourhood-scale urban riparian ecosystem classification. Ecol. Indic. 2017, 72, 330-339.

57. Cullum, C.; Rogers, K.H.; Brierley, G.; Witkowski, E.T. Ecological classification and mapping for landscape management and science: Foundations for the description of patterns and processes. Prog. Phys. Geogr. 2016, 40, 38-65. [CrossRef]

58. Cullum, C.; Brierley, G.; Perry, G.L.; Witkowski, E.T. Landscape archetypes for ecological classification and mapping: The virtue of vagueness. Prog. Phys. Geogr. 2016, 41, 95-123. [CrossRef] 